Journal of Islamic Medicine

Volume 2 (4) (2018), Pages 8-13

\title{
Upaya Peningkatan Aktivitas Atletik Siswa Dalam Pembelajaran Pendidikan Jasmani Dan Kesehatan Pada Siswa Kelas VI SDN Kertajaya IX Dengan Metode Demonstrasi
}

\author{
Niah Masriah $^{1}$ \\ ${ }^{1}$ SDN Kertajaya Kec Gubeng Kota Surabaya \\ Email : niahmasriah1@gmail.com
}

\begin{abstract}
Student achievement, especially on physical education subject of sport and health is not separated from teacher role to design an effective learning system one of the teacher's effort to improve effective learning is by increasing student activity with various technique, that is by doing various learning by using approach method an activity-based athletic game in particular.This research is hopefully able to provide and develop in the study of learning alternatives that remain and can improve the quality of maximum learning outcomes, and can be used as a reference for subsequent research.
\end{abstract}

Keywords : Athletic, Activity, Physical

\section{PENDAHULUAN}

Pendidikan di Indonesia selalu mengalami pembaharuan dalam rangka mecarai struktur kurikulum,sistem pendidikan dan metode pengajaran yang efektif dan efisien.Upaya tersebut antara lain peningkatan sarana dan prasarana peserta didik serta perubahan dan perbaikan kurikulum. Sekolah sebagai suatu institusi atau lembaga pendidikan idelanya harus mampu proses edukasi, sosialisasi,dan transmormasi dengan kata lain sekolah yang bermutu adalah sekolah yang mampu berperan sebagai proses edukasi (proses pendidikan yang menekankan proses mendidik dan mengajar), peoses sosialisasi ( proses bermasyarakat terutama dalam peserta didik) dan wadah proses transformasi (proses perubahan tingkah laku kearah yang lebih baik/ lebih maju)

SD Negeri Kertajaya IX Gubeng Surabaya merupakan salah satu sekolah Negeri yang mempunyai input atau masukan siswa yang memiliki prestasi belajar yang bervariasi. Pada tahun pelajaran 2012-2013 batas terendah ebtanas murni/NEM SD masuk SD Kertajaya IX adalah 32 Batas tuntas nilai penjaskes SD Negeri Kertajaya IX untuk tahun pelajaran 20122013 adalah 6.00, masalah proses belajar mengajar pada umumnya terjadi dikelas dalam hal ini dapat berati segala kegiatan yang dilakukan guru dan anak didiknya di suatu ruangan dalam melaksanakan KBM ,dan implementasi kurikulum serta evalusinya (1).

Pada zaman yunani, berlari bukan saja kegiatan keagamaan tetapi juga dipertarungkan untuk memperoleh hadiah sang raja bahkan untuk mencapainya bukan saja melalui kemenangan, tetapi kadang kadang juga kematian bagi yang kalah. Yunani yang terkenal berkebudayaan tinggi itu, kemudian mengubah dan menata peraturan demi pertumbuhan atletik. Akhirnya perlombaan baik juara maupun yang kalah tetap bersahabat sesuai pertarungan itu. Pada 
pertengahan abad ke-19 Inggris telah mengembangkan cabang olahraga ini ke seluruh dunia. Bahkan beberapa perguruan telah menyelenggarakan perlombaan ateltik, seperti Exter Colagge tahun 1850, di Indonesia tercatat sejak tahun 1930-an dimana pemerintah hindia belanda atletik sebagai salah satu mata pelajaran diseokalh-sekolah. Akhir perkembangan selanjutnya adalah persatuan atleik seluruh Indonesia (PASI) Pada tanggal 03 September 1950 di semarang kegiatan pertama tercatat pada tahun itu juga ya ini dengan meyelenggarakan perlombaan Atletik di bandung,perlombaan memilih dua Atletik untuk Asian Game pertama di New Dehli tahun 1951, Istilah Atletik berasal dari Yunani. Perlombaan yang dilakukan di lintasan (trak) dan di lapangan FAIL. Istilah atletik dalam bahasa inggris : atletiek dalam bahsa jerman mempunyai pengertian yang luas meliputi berbagai cabang olahraga yang bersifat perlombaan atau pertandingan, termasuk renang, bola basket, tenis, sepak bola, senam dan lain-lain. Peningkatan dan pengembangan kemampuan profesionalisme tersebut meliputi berbagai aspek antara lain : kemampuan guru dalam menguasai kurikulum dan materi pelajara, kemampuan dalam menggunakan metode dan teknik evaluasi kemampuan dalam memanfaatkan sarana dan prasarana dalam proses belajar.

\section{Tujuan Penelitian}

Penelitian tindakan ini bertujuan untuk memotivasi guru agar dalam pembelajaran penjaskes senam atau gemar menggunakan metode demonstrasi, agar siswa memiliki konsep dasar atletik serta sikap disiplin, kerja keras, ingin tahun dan memecahkan masalah untuk menyesuaikan diri dengan perubahan-perubahan di sekelilingnya.

\section{Kualitas Pengajaran Penjaskes}

Adanya beberapa kendala dalam pembelajaran yang dapat digunakan sebagai bahan perbaikan dalam pembinaan untuk meningkatkan kemampuan belajar penjaskes. Permasalahan-permasalahan tersebut antara lain menyangkut kemampuan guru, kemampuan siswa, miskonsepsi, keterbatasan sarana prasarana, dan belum dimanfaatkannyakapasitas sumber belajar kegiatan pembelajaran PJOK. Dalam hal ini diperlukan rancangan pengajaran yang berbentuk design instruksional yang memungkinkan terciptanya interaksi belajar mengajar dan melatih anak untuk ikut aktif dalam berkembang keterampilannya selama kegiatan belajar berlangsung. Contoh : guru mendemonstrasikan ketrampilan aktivitas atletik dihadapan murid-murid.

\section{Upaya Menumbuhkan minat murid agar senang melakukan demonstrasi}

Upaya untuk menumbuhkan minat siswa untuk senang dan gemar melakukan demonstrasi adalah usaha guru agar murid-murid mendapatkan kemampuan-kemampuan tertentu dalam belajar penjaskes yang dapat digunakan dalam kehidupan sehari-hari misalnya, menggunakan saran yang berhubungan dengan ketrampilan aktivitas atletik. Adapun Modelnya sebagai berikut :

a. Menanamkan arti pentingnya mau melakukan demonstrasi aktivitas atletik.

b. Menciptakan interaksi belajar mengajar yang memungkinkan murid mendapatkan pengalaman dalam aktivitas pembelajaran.

\section{Pembelajaran tentag aktivitas Atletik}

Atletik adalah suatu cabang olahraga yang tertua, yang telah dilakukan oleh manusia sejak zaman purba sampai dewasa ini. Bahkan boleh dikatakan sejak adanya manusia di muka bumi ini Atletik sudahada. Gerakan gerakan yang terdpat dalam cabang olahraga atletik,seperti berjalan,berlari,berlompat,melempar adalah gerakan yang dilakukan oleh manusia didalam kehidupannya sehari-hari. 


\title{
Lari Jarak Pendek ( sprint)
}

Lari cepat atau sprint yaitu suatu perlombaan lari dimana semua peserta berlari dengan kecepatan penuh yang menempuh jarak $00 \mathrm{M}, 200 \mathrm{M}$,dan $400 \mathrm{M}$.

\author{
Pada umumnya kita mengenal 3 Cara melakukan start atau tolakaan yaitu : \\ 1. Start Berdiri ( Standing Start) \\ 2. Start melayang ( Flying start ) \\ 3. Start Jongkok ( Crouching Start ).
}

\section{METODE}

\section{Lokasi Penelitihan}

Penelitihan tindakan kelas ini di lakukan di kelas VI Semester 1 Sekolah Dasar Negeri Kertajaya IX Gubeng -Surabaya.Tahun pelajaran 2015-1016

\section{Rencana Kegiatan}

Kegiatan penelitihamn ini di rencanalkan mulai bulan Agustus 2015 dengan di awali dengan kegiatan persiapan membentuk kelompok menjadi 3 kelompok kegiatan .Sebagai penjajakan memperoleh data-data permasalahan dan tindakan yang telah di ;akukan oleh guru kelas dan dilanjutkan membahas kerja masing-masing kelompok tersebut serta merencanakan dan menetapkan tindakan .Rancangan penelitian ini menggunakan model ketrampilan proses .

a. Proses penelitian putaran 1 atau siklus 1 di laksanakan tanggal 19 s/d 24 Juli 2015

b. Proses penelitian putaran ke II atau siklus II di laksanakan tanggal 26 s/d 31 Juli 2015

c. Proses penelitihan putaran III atau siklus III di laksanakan tanggal $02 \mathrm{~s} / \mathrm{d} 07$ Agustus 2015.

\section{Cara Kerja}

\section{Planing Penelitian}

Penelitian ini melalui siklus yang mendesak dan berkelanjutan direnanakan. Dengan melaksanakan 4 Siklus ,setiap siklus dengan 3 tindakan yaitu : Pemanasan Konsep berani melakukan demontrasi melalui rangsanagan dengan suatu contoh skill Guru dalam demontrasi Aktivitas Atletik ,penciptaan kondisi dan pemberian kesempatan untuk melakukan demontrasi altivitas Atletik, meski belum sempurna di depan teman-temanya. Hal ini di lakukan dengan wujud pengoptimalan penggunaan metode tersebut serta pemberian dorongan ( motivasi ). Perencanaan tindakan kelas pada setiap siklus di susun bersama berdasarkan hasil pengamatan dan refleksi penulis sebagai pelaku utama dalam penelitian ini.

Setiap siklus melalui tahapan observasi dan perencanaan tindakan ,Implementasi tindakan dan monitoring penelitian ,refleksi hasil penelitian dan pengembangan.

\section{Implementasi Tindakan .}

\section{Siklus I}

\section{Tindakan I}

Guru menamkan pentingnya melakukan demontrasi dengan memberikan ransangan ( stimulus ) deengan menunjukan ransangan ( stimulus ) dengan menunjukan lapangan Olahraga ,secara kebetulan sebelumnya pelajaran Penjaskes banyak siswa yang mendapat nilai kurang dan perlu mengalami perbaikan. Pada kesempatan tersebut guru menanyakan mengapa mereka mendapat nilai kurang dan menanamkan pentingnya mau bertanya,sering 
menanyakan ,sering melatih dan mencoba menyelesaikan soal-soal ,sebagai stimulus Guru memberikan suatu cerita sebagai murid yang aktif mengikuti petunjuk dan pengarahan guru Caranya dengan memberikan tugas di rumah untuk gemar dan senang mengamati peristiwa alam disekeliling rumah atau lingkungan sekitar rumah, misanya memperhatikan dan mencatat media belajar di Lapangan Olahraga.

\section{Tindakan 2}

Menyususn rencana pembelajaran dan melaksanakan dengan memberikan kesempatan pada murid untuk bertanya jawab tentang demontrasi yang ada hubungannya dengan Aktivitas Atletik yang di lakukan di lapangan Olahraga.

\section{Tindakan 3}

Memotivasi dengan cara memberikan acungan jempol atau pujian kepada siswa yang baik dan benar dalam menerapkan kegiatan aktivitas Atletik .

\section{Siklus II \\ Tindakan I}

Menemukan pentingnya melakukan demontrasi Aktivitas Atletik .Yang intinya bahwa siapa yang mau mencoba demontrasi akan berguna bagi diri sendiri dan orang lain .menugaskan anak untuk mempelajari dan mempersiapkan alat-alat yang akan di gunakan sebelum melakukan suatu demontrasi berikutnya .

Tindakan 2

Merencanakan pembelajaran dan melaksanakan dengan menerapkan metode demontrasi dalam pelajaran Penjaskes Berikutnya.

\section{Tindakan 3}

Pemberian motivasi atau dorongan dengan memberikan nilai kepada anak anak yang mau melakukan demontrasi Aktivitas Atletik .

\section{Siklus III}

\section{Tindakan I}

Mengingatkan kepada siswa pentingnya melakukan demontrasi dalam pembelajaran Penjaskes agar murid-murid mendapatkan kesan-kesan dalan pikiran ,ktrampilan dalam menggunakan lapangan Olahraga sehungga akan tercapai sasaran pembelajaran sebagai berikut :

a. Pengetahua ,gagasan ,dan konsep terhadap aktivitas Atletik

b. Kemampuan yang dapat di latih atau di gunakan :

c. Ketrampilan dalam melakukan Atletik lari Sorint

d. Ketrampilan dalam meningkatkan Kecepatan dalam lari

e. Ketrampilan lompatan

f. Kemampuan mengenai dasar-dasar dalam teknik atletik ( lari,lempar ,atao tolak ) dengan di dasari konsep yang benar .

\section{Tindakan II}

Merancang dan melaksanakan pembelajaran Penjaskes dengan lebih mengoptimalkan metode demontrasi serta metode pemecahan masalah sehingga lebih memberi permasalahan yang lebih menantangaMisalnya :

a. Meningkatkan teknik dalam melakukan aktivitas atletik 
b. Membantu proses pembelajaran .

Tindakan III

Pemberian Motivasi atau pijian dan Nilai ,Nilai di berikan kepada anak yang berpartisipasi baik atau aktif melakukan demontrasi

Siklus IV

Tindakan I

Mengingat pentingnya melakukan demontrasi Aktivitas Atletik dan menceritakan pengalaman kepada teman-teman baik pengalaman senang maupun tidak menyenangkan .

\section{Tindakan 2}

Untuk mengembangkan keberanian anak untuk melakukan demontrasi guru merancang dan melaksanakan pembelajaran dengan curah gagasan untuk menandai-andai seolah-olah dirinya sebagai Atlit Profesional.

Tindakan 3

Memberikan motivasi berupa pujian dan rangsangan agar berani melkukan demontrasi Aktivitas Atletik ,murid di minta untuk menceritakan pengalamannya.

\section{A. Monitoring penelitian}

Tindakan pada setiap siklus selalu di pantau oleh anggota peneliti yang lain .Dalam memantau setiap tindakan tersebut dengan menggunakan lembar pengamatan /observasi .sebagai alat bantu untuk melihat keaktifan siswa dalam melakukan demontrasi.

Tabel 2

Keaktifan demontrasi Aktivitas Atletil Murid Kelas VI SDN Kertajaya IX Gubeng Surabaya.

\begin{tabular}{|c|c|c|}
\hline Siklus & Tindakan & $\begin{array}{c}\text { Melaksanakan } \\
\text { Demontrasi }\end{array}$ \\
\hline 1 & 1 & 10 \\
& 2 & 11 \\
& 3 & 12 \\
\hline & Rata-rata & $11=27.50 \%$ \\
\hline II & 1 & 13 \\
& 2 & 14 \\
& 3 & 15 \\
\hline III & Rata-rata & $14=35.00 \%$ \\
& 1 & 17 \\
& 2 & 21 \\
\hline & 3 & $19=47.50 \%$ \\
\hline IV & Rata-rata & 21 \\
& 1 & 23 \\
& 2 & $23=57.50 \%$ \\
\hline
\end{tabular}

Dari tabel 2 dapat kita lihat hasil pada siklus.pada siklus i Tindakan i.: dari 40 murit ada 10 Orang yang mau melaksanakan demontrasi walaupun masih belum sempurna 
melaksanakannya.Analisis dan refleksi tersebut di susun Rencana pembelajaran yang memberikan kesempatan kepada murid untuk menayakan langkah-langkah dalam melakukan demontrasi.

Tabel 3

Rata -rata prosentasi keberanian Murid untuk melakukan Demontrasi Penjaskes Murid Kelas IV SDN Kertajaya IX Gubeng - Surabaya.

\begin{tabular}{|c|c|}
\hline Siklus & \% Melakukan Percobaan \\
\hline II & 27,50 \\
III & 35,50 \\
IV & 47.50 \\
\hline
\end{tabular}

Dari keseluruhan siklus yang telah di lakukan dapat disimpulkan bahwa guru telah berupaya menumbuhkan keberanian murid -murid untuk gemar senang dan timbul kemauan untuk melakukan demontrasi di dalam kelasnya.Hal ini nampak jelas dalam tabel 3 setiap siklus tampak ada dampak positif yang ke arah pertumbuhan keberanian untuk melakukan demontrasi.

\section{PENUTUP}

\section{Kesimpulan}

Penetapan model dan prosedur dalam penilaian ini di laksanakan pada teori mengajar terutama pada prinsip belajar dan pemberian motivasi ( dorongan ). Model yang di gunakan dalam penelitian dengan model ketrampilan proses, dalam satu model di tetapkan dengan empat proses.

\section{Saran}

Model ini pada hakekatnya layak di gunakan dan di kembangkaoleh guru Yang mengalami permasalahan yang sejenis. Kreativitas guru dalam mengembangkan kemauan dan kemauan kreativitas murid sa sangat di perlukan

\section{DAFTAR PUSTAKA}

1. Depdiknas ,2002.Kurikulum Berbasis Kompetensi standart Pelajaran pengetahuan Sosial,Sekolah Dasar Madarasah Ibtidaiyah .Jakarta: Puskur

2. Dit PTK 3D.Priyatmi,E.T.Tanpa tahun.Kurikulum Berbasis Kompetensi : Konsep dasar dan perapanya .

3. Ratnaningsih,U,O.1998/1999,Perspektif Global.Pekanbaru: Depdibud Dirijen. Dikti Proyek Guru Sekolah Dasar.

4. Toyibin,M.A.dan Djahri,A.K.1991/1992.Pendidikan Pancasila II,Jakarta: Depdikbud Dirijen Dikti Proyek Pembinaan Tenaga kependidikan. 